\title{
Exploration of interstitial habitats by the phytophilous Ostracod Cypridopsis vidua (O.F. Müller) : experimental evidence
}

\author{
J.R. Rocal \\ Dan L. Danielopol2
}

Keywords : Ostracodes, Cypridopsis vidua, interstitial habitat.

Cypridopsis vidua (O.F.M.) lives within dense stands of Chara fragilis Desv. in Mondsee. The species develops fast and is very voracious, feeding on the "Aufwuchs" of the Chara stems. Under experimental conditions, $C$. vidua actively explores the interstitial of a fine gravel sediment. The ostracodes are also able to find their way out of the interstitial labyrinth.

The limited colonisation of deep groundwater habitats by $C$. vidua (c.g. in the Danube and the Rhone valleys the species lives in superficial aliuvial sediments located near the bottom of surface waters) is presumably due to its high energetic requirements.

C. vidua recognises the chemical alarm signals of predators such as the fish $A$ bramis brama (L.); the ostracods react by drecreasing their motility in both the surface and the interstitial habitat.

Recherche d'habitats interstitiels par l'Ostracode phytophile Cypridopsis vidua (O.F. Müller) : mise en évidence expérimentale

Mots clés : Ostracodes, Cypridopsis vidua, habitat interstitiel.

Cypridopsis vidua (O.F.M.) vit au sein de la végétation très dense de Chara fragilis Desv. du lac de Mondsee. Cet Ostracode qui se développe rapidement est très vorace et se nourrit à partir des « Aufwuchs " qui se développent sur les branches de Chara. Dans des conditions expérimentales $C$. vidua est capable d'explorer activement l'habitat interstitiel réalisé par des graviers fins. Les individus de cette espèce peuvent alors retrouver leur voie pour sortir de ce labyrinthe interstitiel.

C. vidua vit également dans les sédiments superficiels sous le cours subaérien du Danube et du Rhône. La colonisation limitèe des habitats souterrains profonds par cette espèce est vraisemblablement due à ses besoins énergetiques élevés.

C. vidua reconnaît les signaux d'alarme chimique de prédateurs tels que les poissons (Abramis brama (L.)) ; les indjvidus réagissent en abaissant leur mobilité tant dans leur habitat de surface qu'interstitiel.

\section{Introduction}

Rouch \& Danielopol (1987) analysed the different ways of colonisation of subterranean waters by epigean dwelling animals. They contrasted two main patterns called «the active migration model " and " the refuge under constrains paradigm ". The former scenario considers that organisms actively penetrate underground especially during periods of time

1. Instituto d'investigacions d'Alta Muntanya, Aptdo 21 E-25530 Viella y Instituto Pirenaico de Ecología, Aptdo 64, I:-22700 Jaca, Spain.

2. Limnological Institute, Austrian Academy of Sciences A-5310 Mondsee, Austria. when the surface environment does not experience catastrophic disturbances. In particular, animals displaying preadaptive traits for life in underground habitats, and which have wide ecological tolerances (generalist species) are predisposed to colonise the hypogean realm. Such species have in many cases a wide geographical distribution in surface waters. The " refuge under constraints " model considers that the exclusively subterranean dwelling fauna originated either during periods of time when the epigean environment changed drastically or under the pressure of strong animal predators obliging the animals to take refuge in more stable and protective habitats (Botosaneanu \& Holsinger 1991, Sket 1986, 1988, Wägele 1989). In the absence of such habitats 
the animals could become locally extint. A third option for the origin of subterranean fauna is possible too, i.e. surface dwelling animals passively penetrates subsurface habitats, where once trapped they build stable populations and evolve troglomorphic traits. Wilkens (1988) considers that this is the way in which troglobite populations of the fish Astyanax fasciatus Cuv. (characid, colonising various mexican caves) originated.

Rouch \& Danielopol (1987) emitted doubts about the validity of " the refuge under constraints " scenario. It was pointed out that there are few solid empirical evidence for such model.

The pressure of fish predation as a cause which could contribute to the origin of certain subterranean crustaceans was suggested more recently by Wägele (1989). At our knowledge no published data exist which should support this contention. However, we consider that the three models explaining the origin of some of the subterranean aquatic fauna can be tested by a combination of field observations with laboratory experiments. The present note represents a preliminary tentative supporting such an approach.

We review first the field distribution of the phytophilous ostracod Cypridopsis vidua (O.F.M.) which inhabitates subsurface habitats (interstitial spaces of alluvial sediments and cave waters). Then we present our observations on the way this ostracode penetrates into interstitial spaces under two contrasting conditions, i.e. without any environmental pressure and under the constraints of the fish (predator) signals. If this ostracod species would colonise freely the interstitial habitat just as an exploratory activity then some arguments for the active migration model are gained. At the contrary an active retreat into the interstial spaces of sediments of $C$. vidua which recognises the signals of a predatory fish would give empirical support to the refugium under constraints hypothesis as argumented by Wägele (op. cit.).

Danielopol $(1983,1991)$ and Creuzé des Chatelliers (1991) showed that the widely distributed phytophilous ostracod species, Cypridopsis vidua colonise the alluvial sediments of the Danube and Rhône valleys. Considering their origin in the interstitial habitats of the Danube, Danielopol (1991) suggested that C. vidua actively penetrated underground. For this species, from a by passed channel of the Rhône,
Creuzé des Chatelliers \& Marmonier (1990) suggest that the animals could penetrate underground passively during the process of infiltration of surface water into the superficial alluvial sediments.

Field observations in lake Mondsee showed us that $C$. vidua prefers littoral areas covered by dense macrophytes as Chara fragilis Desv.. Experiments with fishes which prey on this ostracod species (Mbahinzireki et al, 1991) showed that those individuals which select dark backgrounds are better able to escape to their predators.

Before testing the two alternative hypothesis mentioned above it was necessary to obtain more informations on the ways $C$. vidua moves and feeds under experimental conditions within various substrates macrophytes - (e.g. on or between Chara fragilis stems) and within interstitial spaces of unconsolitated sediments (e.g. between the grains of coarse sand and gravel). We observed the movement of $C$. vidua with and without stimuli of fish predator. In this respect we chosed chemical « alarm » signals produced by fishes (see next section). Field data on the occurence of $C$. vidua in interstitial habitats will be presented using the published informations in Danielopol (1983, 1991) and Creuzé des Chatelliers (1991).

\section{Material and methods}

\subsection{General informations}

The species Cypridopsis vidua used in the experiments is a widely distributed ostracod (Löffler \& Danielopol 1978). This ostracode has a globular shape with several pigmented stripes (brown, black of green) on the carapace. The length of adult specimens is around $0.6 \mathrm{~mm}$ and the last stages of juveniles are between 0.3 and $0.5 \mathrm{~mm}$. Other morphological and characteristics are available in Lupherova (1974), and Casale \& Danielopol (1990). C. vidua is common in ponds and lakes with abundant submerged vegetation. Though less frequently, it is also possible to find it in large rivers (Danielopol 1983, 1991, Creuzé des Chateltiers 1991). Mbahinzireki et al. (1991) and Danielopol (unpubl, data) have observed that $C$. vidua lives in Mondsee within dense stands of Chara fragilis in the littoral zone, feeding mainly on the "Aufwuchs" developed on the stems and leafs. 
Living specimens of $C$. vidua were sampled from macrophytes (Chara fragilis) collected in Mondsee, at a depth of 1-2 m out of the shore using a net and a rake. Samples were washed through a sieve of $2 \mathrm{~mm}$ and subsequently through $400 \mu \mathrm{m}$ and $200 \mu \mathrm{m}$ sieves and the specimens were extracted by pippeting.

Cypridopsis vidua from the Danube and the Rhône alluvial sediments was obtained using a BouRouch pump with which it was extracted either samples of 3 liters water and sediment (Danielopol 1983) or 10 liter samples (Creuzé des Chatelliers 1991). In order to compare the densities of $C$. vidua populations occuring at the surface of the sediments with those from the deeper subsurface sediment layers Danielopol (1983) extracted the epigean dwelling ostracodes with the Bou-Rouch pump, which had a $10 \mathrm{~cm}$ lenght screened tube fixed partly between 0 and $5 \mathrm{~cm}$ depth into sediment.

\subsection{Feeding behaviour}

To observe the feeding behaviour of $C$. vidua, cultures under control conditions (permanent illumination, uniform temperature, $20^{\circ} \mathrm{C}$, aereted lake water) were done using a $30 \mathrm{~mm}$ diameter tubular PVC vial closed with a $60 \mu$ sieve. Groups of 20 and 5 specimens (adults) were kept in different feeding conditions (Table III).

\subsection{Interstitial exploratory behavior within a granular habitat}

Experiments observing the exploratory behaviour of the interstitial habitat of $C$. vidua were monitored and recorded with a video camera (Panasonic CCD-MF1 and a Sony recorder). Details of exploratory behaviour were analysed by means of photographs from the video tape.

To simulate an interstitial habitat that would allow the experimental observations of the exploratory behavior by $C$. vidua, microaquaria of $1,5 \mathrm{~cm}$ length, $2 \mathrm{~cm}$ height and $0.5 \mathrm{~cm}$ width, were designed. These microaquaria were made of standard glass micro-slides joined by cement, filled with fine riverine gravel (0.5-1.5 mm diameter), leaving interstices no larger than $2 \mathrm{~mm}$ of diameter. White and transparent (quarzite) riverine gravel were selected to increase optical contrast and optimising the video observations between animals and background. Microquaria were divided in four parts (1.surface level of water, 2.upper, 3.middle and 4.low interstitial zones) by blue marks to distinguish animal position.

Two series of experiments (Table IV) were carried out using either single specimens in order to study the individual exploratory behaviour) or groups of 20 specimens which allowed to unterst and the population trend of the exploratory process. The single specimen exploratory behaviour was studied by means of two trials (twice replicated), creating two extreme situations (higher and lower needs conditions).

We used groups of 20 specimens (10 adults and 10 juveniles) ; three trials were performed in which we varied the environmental situations (with and without food). The position of the food into microaquarium was changed with or without alarm stimuli represented by an aliquot of fish water from a tank whith fishes (Abramis brama (L.) ).

During video recording the microaquarium was illuminated by cold light through a fibre-glass system from the sides; the vessel was filled completely with lake water. In all the trials, the time of experiment was 5 minutes. During this period the ostracod behaviour was described in qualitative terms.

\section{Results}

\subsection{Occurence of $\boldsymbol{C}$. vidua in interstitial habitats of the Rivers Danube and Rhône}

During 1979-1981, one of us (D.L.D.) investigated a backwater of the Danube, the Eberschut twasser, near Vienna. The depth of this Danube old arm is less than $10 \mathrm{~m}$ deep. Near the shore the bottom is formed by sandy-gravel sediments within which accumulate high amount of organic detritus produced mainly by macrophytes, especialy Phragmites. During the spring and autumn of 1980 an abundant population of $C$. vidua developed at the surface of the sediments and within the sediments. The intertsive sampling program of the alluvial sediments (Danielopol 1983, 1989, 1991) showed that $C$. vidua is more or less evenly distributed at the surface of the sediment over an area of $30 \mathrm{~m}^{2}$ but displays a patchy distribution within the sediment at $0.5 \mathrm{~m}$ deep (Table 1). So $91 \%$ percentage of the 11 samples taken at the water-sediment interface contained C. vidua and the mean number per sample was 8 individuals. At $0.5 \mathrm{~m}$ deep into the sediment from 
12 samples during the cold weather (February) only $16 \%$ were positive while during the other seasons the number of samples containing this ostracod species varied between $33 \%$, in July, and $58 \%$, in October. The mean number of specimens per sample unit was low in winter $(0.4$ specimens) and maximal in autumm ( 5 specimens). At a deeper layer (1.2 m deep) $C$. vidua occured unfrequently and in very low number of specimens (Table I). One had the feeling that $C$, vidua established within the interstitial habitat a permanent population only in the upper sediment layer $(0.5 \mathrm{~m}$ deep), Here $C$. vidua persists, mainly in well oxygenated areas (see data in Fig. 8, Danielopol 1991) i.e. which have more than $5 \mathrm{mg} / \mathrm{l}$ dissolved oxygen.

At this sampling site large amounts of organic detritus accumulate within the interstitial spaces of these alluvial sediment, especialy within the first $1.5 \mathrm{~m}$ depth. Here the plant detritus is commonly covered with bacteria and fungi (e.g. Fig. $1 \mathrm{~A}$ ). At $2 \mathrm{~m}$ deep into the sediment of the same areas no $C$. vidua have been encountered and there is a drastic reduction in the organic matter and oxygen concentration (Danielopol 1983, 1991). The particulate organic matter is mainly represented by refractory substances. Cocoid bacteria occur on fine grains of sediments (Fig. 1 B).

The presence over one year of a population of C. vidua within the surficial sediment layer $(0.5 \mathrm{~m}$ deep) located preferencialy in the well oxygened part of the sediments suggested to Danielopol (1991) that the ostracods actively dispersed into the sediments and settled in the area where suitable living conditions were present.

In the Rhône, Creuzé des Chatelliers (1991) investigated intensively three geographic areas closely located to Lyon and Montélimar. The Rhône at the site Donzères-Mondragon, at the confluence with the river Ardèche, is characterised during the summer by low water stand and the development of large amounts of algae on the bottom of the river. The alluvial sediments are represented by coarse gravel within which accumulate organic matter from the surface of the riverbed. Several ostracod species develop abundantly during August (i.e. Potamocypris similis Müller, Limnocythere inopinata Baird and Cypridopsis vidua) at $0.5 \mathrm{~m}$ depth sediment

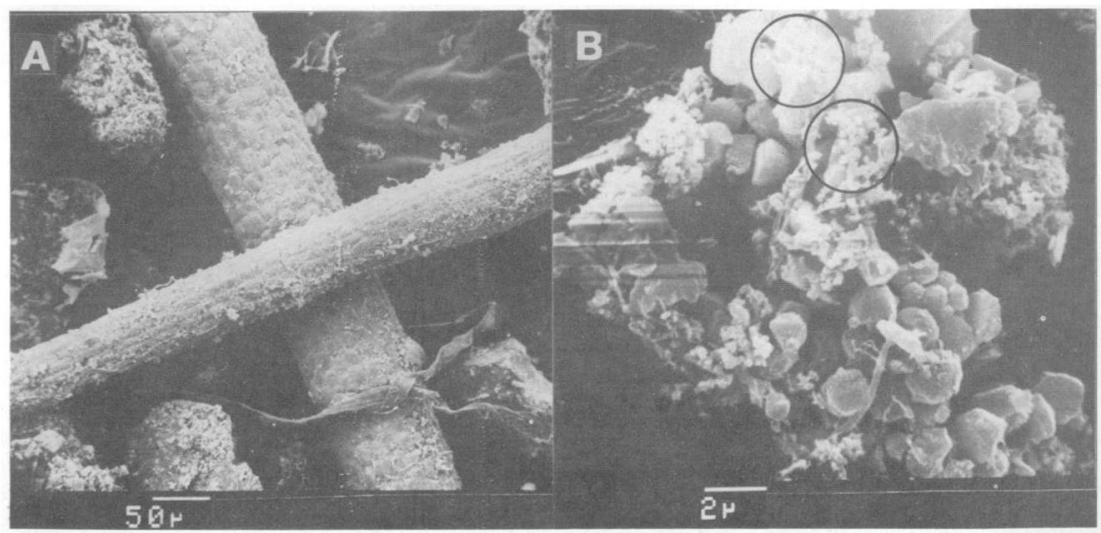

Fig. 1. Details of Eberschuttwasser sediment.

A : Plant detritus from a $0,4 \mathrm{~m}$ deep layer. B : Organic detritus and bacteria (encircled) from the $2 \mathrm{~m}$ deep layer. 
Table I. C. vidua at Eberschültwasser (Danube) (Data from Danielopol 1963, figs 56-57, p. 98-99).

\begin{tabular}{|c|c|c|c|c|c|c|}
\hline Sample & $\begin{array}{l}\text { Depth } \\
\text { (m) }\end{array}$ & Date & $\begin{array}{l}\text { Sampling } \\
\text { units }\end{array}$ & $\begin{array}{c}\text { Samples } \\
\text { with } C \text {. vidua }\end{array}$ & Total & $\begin{array}{l}\text { Mean } \\
\text { indiv. }\end{array}$ \\
\hline 1 & 0 & 14.05 .80 & 11 & $10(91 \%)$ & 86 & 7.8 \\
\hline 2 & 0.5 & 12.02 .80 & 12 & $2(16.6 \%)$ & 5 & 0.4 \\
\hline 3 & 0.5 & 14.04 .80 & 12 & $4(33 \%)$ & 40 & 3.3 \\
\hline 4 & 0.5 & 31.07 .80 & 12 & $5(41 \%)$ & 20 & 1.6 \\
\hline 5 & 0.5 & 15.10 .80 & 12 & $7(58.3 \%)$ & 65 & 5.4 \\
\hline 6 & 1.2 & 14.05 .80 & 6 & $2(33 \%)$ & 4 & 0.6 \\
\hline 7 & 1.2 & 04.09 .80 & 6 & 0 & 0 & 0 \\
\hline 8 & 1.2 & 17.10 .80 & 6 & 2 & 4 & 0.6 \\
\hline
\end{tabular}

Table II. C. vidua at Donzère-Mondragon (1) and Miribel-Jonage (2). (Data from Creuzé des Chatelliers 1991, Table 3, p. 118).

\begin{tabular}{|c|c|c|c|c|c|c|}
\hline Sample & $\begin{array}{l}\text { Depth } \\
\text { (m) }\end{array}$ & Date & $\begin{array}{l}\text { Sampling } \\
\text { units }\end{array}$ & $\begin{array}{l}\text { Samples } \\
\text { with } C \text {. vidud }\end{array}$ & $\begin{array}{l}\text { Total } \\
\text { indiv. }\end{array}$ & $\begin{array}{l}\text { Mean } \\
\text { indiv. }\end{array}$ \\
\hline 1 & 0.5 & 08.88 & 25 & $20(80 \%)$ & 231 & 9.24 \\
\hline 2 & 0.5 & 08.88 & 34 & $3(9 \%)$ & 10 & 0.09 \\
\hline
\end{tabular}

layer (Creuzé des Chatelliers 1991 and here, Table II). From 25 sampling units $80 \%$ contained C. vidua and the mean number per sample was high ( 9 individuals). At the site Miribel-Jonage, near Lyon, the alluvial sediments are strongly drained by subsurface water and as compared to the previous locality, the sediments are more oligotrophic (Creuzé des Chatelliers 1991). C. vidua occur only seldom and in low numbers. In this area, from 34 sampling units, only $9 \%$ contained this species with less than 1 specimen per sample (Table II).

These data suggest us that the presence of $C$. vidua in the interstitial habitat of the riverbed sediments at $0.5 \mathrm{~m}$ deep at the site Donzère-Mondragon is due to the presence of abundant and/or high quality of food resources. It remains to be determined whether $C$. vidua was drifted passively into sediments during the periods when the river water infiltrates into the subsurface or it penetrated actively during its exploratory activity. The former alternative was suggested by Creuzé des Chatelliers \& Marmonier (1990) for the surface-dwelling ostracods which occur in the surficial sediment layers of the site Miribel-Jonage. The very low number of individuals and unfrequent distribution of $C$. vidua at this site give support to this hypothesis.

Experimental evidence in the next section will argue for a possible active penetration of this species into the interstitial habitats of the DonzèreMondragon.

\subsection{Observations on the feeding and movement of C. vidua}

\subsubsection{Feeding behaviour (Table III).}

Mortality was high when the animals were cultured on barren sediment. This result was compared with a control culture (without any kind of food) and with cleaned $C$. fragilis fragments (without «Aufwuchs 》). These experiments showed that half of the specimens died within 3 days. None survived until the end of the experiment ( 5 days).

Ostracods (Fig. 2 A) feeding only $C$. fragilis fragments (with « Aufwuchs ») remained alive throug. hout the experiment time. In groups of 20 specimens and in long-duration cultures (45 days), all the 
Table III. The culture procedures.

\begin{tabular}{|c|c|c|c|c|}
\hline Culture & $\mathbf{N}^{\circ}$ specimens & Food & $\begin{array}{l}\text { Culture time } \\
\text { (days) }\end{array}$ & $\begin{array}{l}\text { Mortality } \\
\text { ind. dead }\end{array}$ \\
\hline 1 & 20 & $\begin{array}{l}\text { C. fragilis } \\
\text { (with Aufwuchs) }\end{array}$ & 45 & 10 \\
\hline 2 & 5 & Sediment & 5 & 5 \\
\hline 3 & 5 & C. fragilis & 5 & 0 \\
\hline 4 & 5 & $\begin{array}{l}\text { Starvation } \\
\text { conditions }\end{array}$ & 5 & 5 \\
\hline 5 & 5 & $\begin{array}{l}\text { C. fragilis } \\
\text { (without Aufwuchs) }\end{array}$ & 5 & 5 \\
\hline
\end{tabular}

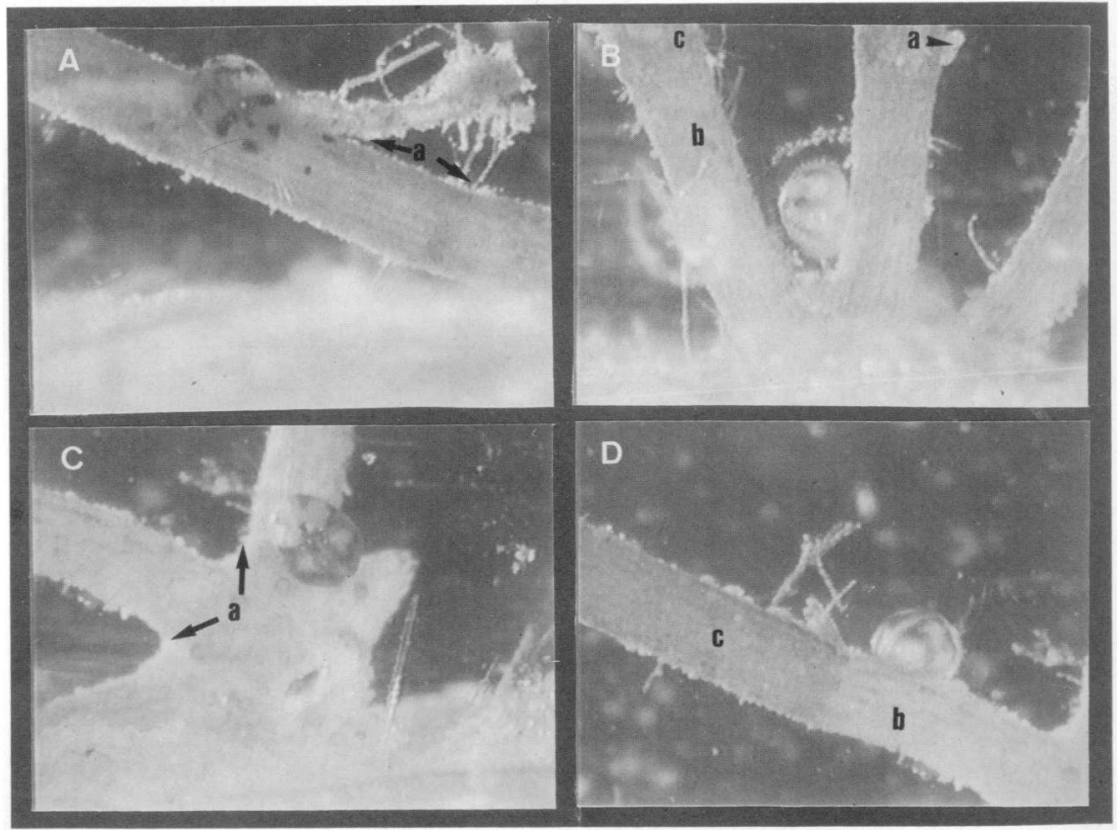

Fig. 2. A.D : Four aspects of Cypridopsis vidua feeding on the stems of Chara fragilis in a microaquarium experimental situation. (a-accumulation of Aufwuchs. b-area which was not cleaned by $C$. vidua. c-area within which $C$. vidua fed on Aufwuchs). 
Table IV. Synoptic protocol of the experiments.

\begin{tabular}{|c|c|c|c|c|}
\hline Experiments & $\begin{array}{l}\text { Food stimuli } \\
\text { (Chara tragilis) }\end{array}$ & $\begin{array}{l}\text { Position (food stimuli) } \\
\text { microaquarium part }\end{array}$ & Trophic status & Fish stimuli \\
\hline \multicolumn{5}{|c|}{ Single specimen } \\
\hline \multicolumn{5}{|c|}{ High needs conditions: } \\
\hline 1 & $\begin{array}{l}\text { small stem } \\
\text { C. fragilis }\end{array}$ & Lower & Starved (12 hors) & -.......- \\
\hline \multicolumn{5}{|c|}{ Low needs conditions: } \\
\hline 2 & with out food & -- & Satiated & $\longrightarrow$ \\
\hline \multicolumn{5}{|c|}{ Groupes of 20 specimens: } \\
\hline 3 & $\begin{array}{l}\text { small stem } \\
\text { C.fragilis }\end{array}$ & Upper & Starved (12 hours) & -..-- \\
\hline 4 & $\begin{array}{l}\text { small stem } \\
\underline{\text { C. fragilis }}\end{array}$ & Lower & Starved (12 hours) & -...-..-- \\
\hline 5 & $\begin{array}{l}\text { small stem } \\
\text { C. Iragilis }\end{array}$ & Upper & Starved (12 hours) & Fish water \\
\hline
\end{tabular}

ostracods were alive for the first 15 days; after 30 days the group had been reduced to the half, that survived until the end of the experiment. Groups of 20 specimens (starved for $24 \mathrm{~h}$ ) ate "Aufwuchs" from nearly $0.5 \mathrm{~cm}$ long fragments of $C$. fragilis (Fig. 2 B, D).

These data indicates that $C$. vidua show a clear preference for feeding on "Aufwuchs" and high energetic requirements perhaps due to its extremly mobile lifestyle (note that this species is a very fast swimmer).

\subsubsection{Exploratory behaviour of the interstitial habitat (Table IV)}

Experiment 1 - food stimuli (small stem $C$. fragilis fragment) in the lower part of the microquarium preceded by 12 hours of starvation (high need conditions). Single specimen used.

Both specimens 1 and 2 took less than one minute to reach the lower part of the microaquarium.
Specimen 1 came up back and went down again several times, always using the same path (Fig. 3). During these movements it visited the food several times, but never stoped on it for more than 10 seconds and never fed. Specimen 2 spent long period of time on the plant (feeding). During this experiment, the ostracod when not sitting or feeding on the plant moved in the horizontal direction between interstices in the lower part of the microaquarium.

Experiment 2 - without food stimuli and without being starved (low need conditions). Single specimen used.

Specimens penetrated faster to the middle part in the two trials, but never reached the bottom. While specimen 2 spent long periods of time immobile in the middle part, specimen 1 have an active movement in all possibles directions; it returned to the surface of the sediment. 


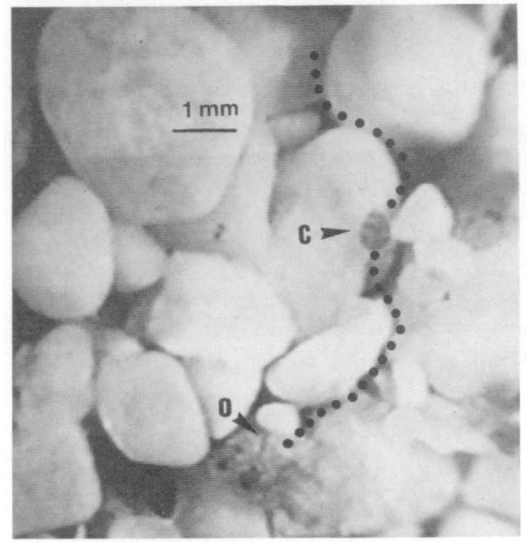

Fig. 3. Fine gravel in a microaquarium : dashed line the path followed by an individual of $C$. vidua (C) : (o-organic detritus).

Experiment 3 - food stimuli fixed at the surface of the sediment preceded by 12 hours of starvation. 20 specimens used.

During the experiment most of the specimens remained in the upper part, sitting on the plant or moving between the interstices. Some of them penetrate into the middle part of the sediment. Only 3 specimens reached the bottoom. All the animals which reached the bottom are juveniles.

Experiment 4 - food stimuli located within the sediment in its lower part preceded by 12 hours of starvation. 20 specimens used.

The number of animals that reached the bottom in this experiment is higher ( $1-5)$ than in experiment 3 (1-3). The middle part of the microaquarium was the most frequented.

Experiment 5 - food stimuli placed at the surface of the sediment, 12 hours of starvation and addition of alarm stimuli (an aliquot of fish water from a tank containing the fish Abramis brama).

The distribution of the ostracods in the microaquarium was similar to that of experiment 3 , but most of them show a noticeable reduction in mobility. The distances covered were shorter and they remained motionless longer than in the other experiments. No active retreat into the interstitial space (a ref uge habitat) due to the fish chemical stimuli was noticed.

\section{Discussion}

Fast penetrations (in less than 5 minutes) through interstitial habitat, reaching the bottom (or, at least, the lower part of the microaquarium), were seen in all the experiments done. In most of the situations the specimens from the bottom of the sediment layer returned to the surface. In general the path going down and coming back was the same. Ostracods show a preference to stay on or around the food, especially when they are starved, but also they can move easely through the interstices without a clear motivation for the food-stimuli. These observations are arguments in favour of the active migration scenario of Rouch \& Danielopol (1987). However, the hypothesis of Wägele (1989) who considers that under the pressure of fish predation various marine benthic crustaceans took refuge into subterranean habitats as coastal sandy sediments, is intuitively plausible as analogic cases are documented for epigean dwelling animals. 
Wright \& Shapiro (1990) and Davidowicz et al. (1990) give pertinent examples of invertebrates as Daphnia and Chaoborus that take refuge in the deeper zones of the lake due to planktivorous fish predators. Davidowiecz et al (1990) demonstrated experimentally that Chaoborus flavicans recognises the fish predators Gastereostus aculeatus through chemical senses. Under experimental conditions, larvae of Chaborus treated with water in which Gastereostus fishes lived, migrated actively to the bottom sediments (the refugial habitat). Therefore, in the case of this invertebrate, a chemical signal could determine the refuge under the constraints of fish predation.

Especially interesting are the data on surface dwelling invertebrates which potentially colonise subterranean habitats too, as caves or riverbed sediments. Such data exist for the isopod Lirceus fontinalis (Holomuzki \& Short 1990, Huany \& Sih 1991) and for several species of Gammarus e.g. G. minus (Holomuzki \& Hoyle 1990), G. pulex (Anderson et al. 1986), G. fossarum (Uiblein et al. 1991), G. pseudolimneus (Williams \& Moore 1985). For these animals chemical cued signals released by predators as fishes or salamanders determine in most of the cases a decrease of their movement. Holomuzki \& Short (1990) showed that in the case of the isopod L. fontinalis which already inhabits sheltered areas where fish predators cannot penetrate remain motionless due to chemical cued signals released by the latter. The analogy of $C$. vidua reactions described previously (see section 3.2 .2 : experiment 5 ) with those of Lirceus and Gammarts here mentioned is striking. We could for the moment not detect a behaviour of $C$. vidua which could be interpreted as a retreat into the interstitial space under the constraints of the fish chemical signals. However we plan additional experiments using more sofisticated devices to observe $C$. vidua in both surface water and interstitial spaces when fishes patrols into the free water.

Especially important will be to chose substrates with larger porous spaces as well as to expose ostracods to fish signals for longer periods of time in order to better understand how these animals perceive the predator and/or how they learn to explore the subsurface interstitial spaces.

Our data suggested also that $C$. vidua does not colonise deep ground waters, for instance, deeper than 1-2 $\mathrm{m}$ depth because of lack of rich energetic resources, especially high quatity food and well oxygenated waters. We showed that this species is a voracious and efficient « Aufwuchs » grazer. Algae (e.g. living diatoms) do not occur in the deeper groundwater layers (e.g. in the Eberschütwasser on Danube at $2 \mathrm{~m}$ deep, Danielopol 1983).

One could predict therefore that $C$. vidua occurs in subterranean habitats where the animals are not constrained by oligotrophic and hypoxic conditions. This prediction is coroborated by the data of Broodbakker (1984). This author mentioned that Cypridopsis aff. vidua in the West Indies occurs in high numbers in wells and caves which contain a rich organic matter supply.

\section{Conclusion}

The present contribution on the ostracod Cypridopsis vidua has to be understood as a preliminary exercise within a long-term project dealing with the origin of interstitial fauna running now at the Limnological Institute in Mondsee.

Our data indicate that a generalist ostracod species as $C$. vidua can penetrate easily into the sediment interstices only for its exploration activity. This fact does not imply necessary the search for food, shelter or escape from predators. In our opinion, these data could be used as an example of the method of colonisation of the subterranean realm by some generalist species according to the active colonisation model as formulated by Rouch \& Danielopol (1987).

Energetic constraints (e.g. food supply) limit the penetration of $C$. vidua into deeper interstitial habitats along the alluvial plains of Rhône and Danube.

Our data does not support the hypothesis of a refuge under constraint. This ostracod species did not move actively into the sediment when or after it detected the fish chemical stimuli. Experiments are needed in order to test the refuge under constraints model.

\section{Acknowledgements}

We are indebt to our friends and colleagues Franz Uiblein (Salz-
burg) and Angel Baltanás (Madrid) for technical help and frui-
ful discussion. This contribution benefited from the financial help
of the Austrian foundation « Fonds zur Forderung der wissens-
chaftlichen Forschung (Project nr. 7881 ) attributed to D.L.D.
and by CICYT of Spanish Governament (Project n ${ }^{\circ}$ PB87-0318)
attributed to J.R. Drs D. Horne (London), M. Creuzé des 
Chatelliers (Lyon), A. Nauwerk (Mondsee) and R. Rouch (Moulis) read critically the manuscript. The former colleague improved the English style of one of the drafts.

\section{References}

Anderson (K.G.), Brönmark (C.), Hermann (J.), Malmquist (B.), Otto (C.) \& Sjörström (P.). 1986. - Presence of sculpins (Cottus gobio) reduces drift and activity of Cammarus pulex (Amphipoda), Hydrobiologia, $133: 209-215$.

Botosaneanu (L.) \& Holsinger (J.R.). 1991. - Some aspects concerning colonization of the subterranean realm, especially of subterranean waters : a response to Rouch \& Danielopol, 1987. Stygologia, 6, 11-39.

Broodbakker (H.W.). 1984. - The distribution and zoogeography of freshwater Ostracoda (Crustacea) in the West Indies, with emphasis on species inhabiting wells. Bijdr. Dierk., 54 : 25-50.

Casale (L.) \& Danielopol (D.L.). 1990. - To see and not to be seen ; the evolutionary problems of the Ostracoda. Bull. Inst. Geol. Bassin d'Aquiraine, 47-48: 227-238.

Creuzé des Chatelliers (M.) 1991 . - Dynamique de répartition des biocénoses interstitielles du Rhône en relation avec des caractéristiques gémorphologiques. Thèse Doct. Univ. Lyon, $161 \mathrm{p}$.

Creuzé des Chatelliers (M.) \& Marmonier (P.). 1990. - Macrodistribution of Ostracoda and Cladocera in a by-passed channel ; exchange between superficial and interstitial layers Stygologia, $5: 17-24$.

Danielopol (D.L.). 1983, - Der Einfluss organischer Verschmutzung auf das Grundwasser-Ökosystem der Donau im Raum Wien und Niederösterreich. Bundesministerium $f$. Gesundheit u. Umweltschutz. Forschungsberichte 5/83:5-160.

Danielopol (D.L.). 1991, - Spatial distribution and dispersal of interstitial Crustacea in alluvial sediments of a backwater of the Danube at Vienne. Stygologia, $6: 97-110$.

Davidowicz (P.), Pijanowska (J.) \& Ciechomski (K.). 1990. Vertical migration of Chaobortus larvae is induced by the presence of fish. Limnol. Oceanogr. $35: 1631-1637$.

Holomuzki (J.R.) \& Short (T.M.). 1990. - Ontogenetic shifts in habitat use and activity in a stream-dwelling isopod. $\mathrm{Hol}$. Ecol., 13 : 300-307.
Holomuzki (J.R.) \& Hoyle (J.D.). 1990. - Effect of predatory fish presence on habitat use and diel movement of the stream amphipod. Gammarus minus. Fresh. Biol., 24 : 509-517.

Huany (C.) \& Sih (A.). 1991. - An experimental study on the effects of salamander larvae on isopods in stream pools. Fresh. Biol., $25:$ 451-459.

Löfler (H.) \& Danielopol (D.L.). 1978. - Ostracoda (Cyprididae). Limnofauna Europaea (Ed. J. Illies). G. Fischer Verlag, Siuttgart.

Lupherova (L.A.). 1974. - Concerning the biology of Cypridopsis vidua (Ostracoda). Transactions Acad. Sci. USSR, 25 : 253-258 (in Russian).

Mbahinzireki (G.), Uiblein (F.) \& Winkler (H.). 1991. - Microhabitat selection of ostracods in relation to predation and food. Hydrobiologia 222 : 115-119.

Rouch (R.) \& Danielopol (D.L.). 1987. - L'origine de la faune aquatique souterraine ; entre le paradigme du refuge et le modèle de la colonisation active. Stygologia. $3: 345-372$.

Sket (B.). 1986. - Ecology of the mixohaline hypogean fauna along the Yugoslav coast. Stygologia, 2 : 317-338.

Sket (B.). 1988. - Fauna of the hypogean waters of the San Andres (Saint Andreros) Island, Colombia. Biol. Vestn., 36 : 77.82 .

Uiblein (F.), Eberstaller (J.), Pöckl (M.) \& Winkler (H.). 1991. - Effects of differential prey mobility on foraging behaviour of a cyprinid fish, Vimba elongata. Ethology, Ecology, Evolution (submitted).

Wägele (J.W.). 1989. - On the influence of fishes on the evolution of benthic crustaceans. Z. Zool. Syst. Evolut. Forsch., 27 : 297-309.

Wilkens (H.). 1988. - Evolution and genetics of epigean and cave Astyanax fasciarus (Characidae, Pisces). Evol: Biol., 23 : 271-367.

Williams (D.D.) \& Moore (K.A.). 1985, - Microhabitat selection by a stream-dweling amphipod : a multivariate analysis approach. Fresh. Biol., $16: 115-122$.

Wright (D.) \& Shapiro (J.). 1990. - Refuge availability : a key to understand the summer disappearance of Daphnia. Fresh. Biol., 24 ; 43-62. 